\title{
Microbiology and Public Beach Safety: Integrated Science for the Protection of Public Health
}

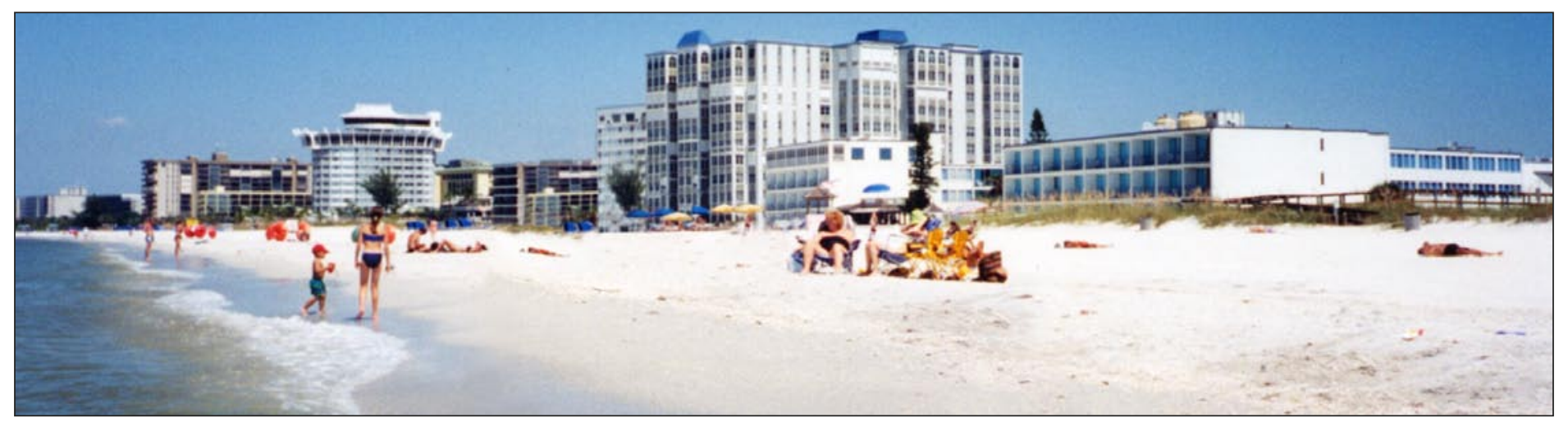

Tourism and recreation are the major drivers of economic development in coastal areas of the United States.

The annual economic impact of local, national, and international visitors to marine recreational beaches throughout the United States is substantial. For example, $\$ 150$ billion was realized just in the States of Florida ( $\$ 57$ billion) California ( $\$ 82$ billion), and Hawaii (\$11 billion) in 2004.

To monitor most of the Nation's public beaches, the microbiological quality of beach water is routinely analyzed for indicators of human and animal fecal pollution (for example, fecal coliforms, enterococci, and E. coli) by local and state regulatory agencies. In addition to these tests, microbiologists at the U.S. Geological Survey (USGS) Florida Integrated Science Center (FISC) have initiated programs to perform additional sampling for microbial indicators and pathogens in coastal waters and also in the sands and sediments from nearshore sites at public beaches. These efforts are in accordance with the recommendations outlined in the Clean Beaches Council's 2005 State of the Beaches Report: Bacteria and Sand, A National Call to Action*, in which an integrated approach to research was requested, with emphasis on the areas of microbiology, geochemistry, and physical sciences, and how they relate to the presence and persistence of bacteria in beach sands. The following issues are being addressed by FISC scientists and academic collaborators:

Indicators and Pathogens in Marine Beach Waters and Sands: Representing the most extensive

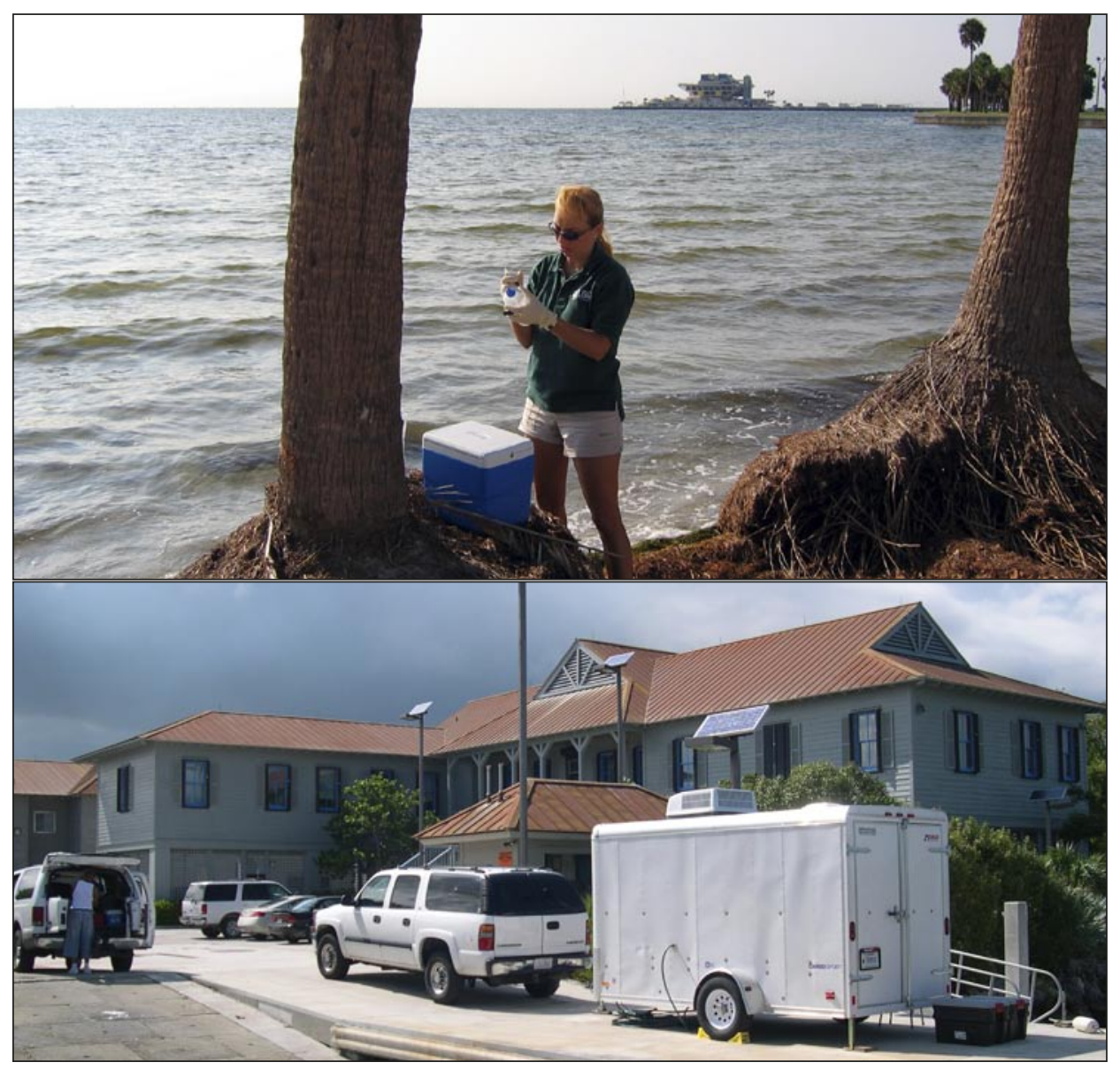

Figure 1. Top: FISC microbiologist collecting water and beach sand for analysis. Bottom: the FISC mobile laboratory allows scientists to process samples in the field. 


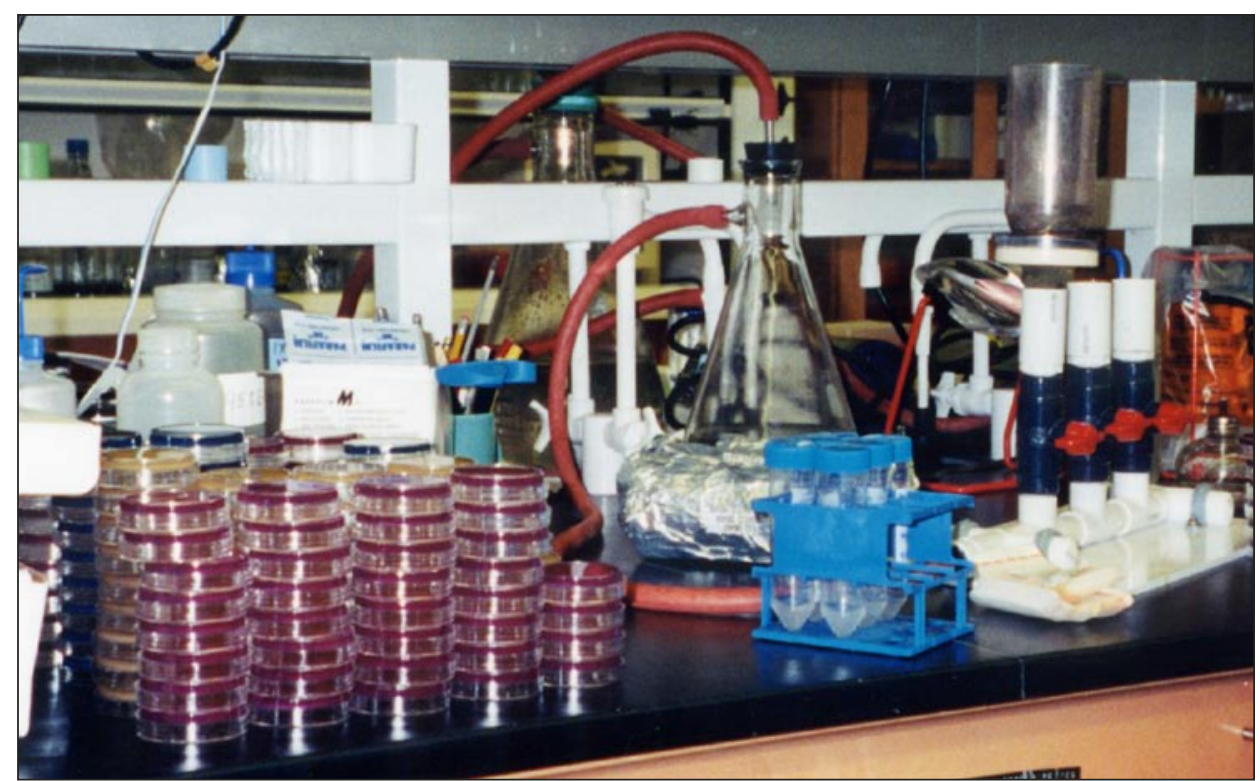

Figure 2. Microbiological media and molecular techniques are used in the laboratory to detect bacteria in samples.

public health microbiology survey of coastal marine beaches, a monthly bacteriological survey was conducted for one year at 10 of the most frequented public beaches in Pinellas County, Florida. Sands and overlying waters were assayed for a suite of indicators of human fecal contamination, as well as total bacteria. The general conclusions were:

- Sands harbor greater concentrations of indicator bacteria relative to the overlying waters.

- Sands and silts may serve as reservoirs of pathogens that can be resuspended into the water.

- Beaches in areas with reduced water circulation had the highest concentrations of all bacterial indicators in the sands.

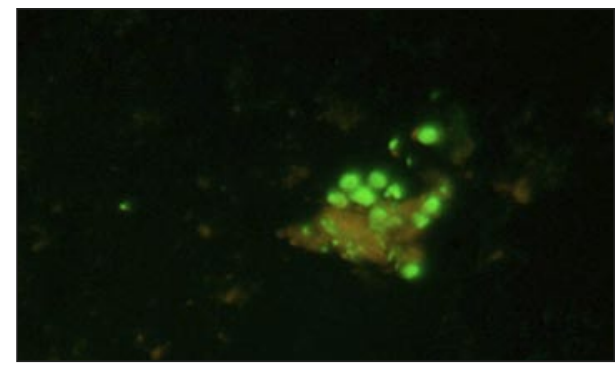

Figure 3. View through the microscope: bacteria (stained bright green for detection) attached to sediment particles.
Submarine Ground-water Discharge: Millions of gallons of fresh ground water seep into the coastal waters of Florida on a daily basis. Studies will provide data on possible microbial and nutrient influences into beach zones that cannot be accounted for by simple measurement of precipitation or runoff.

\section{Beach Sand and Sediment Transport:}

The distance and volume of transported beach sands and sediments increase as the wave energy increases (for example, during storms and hurricanes). Bacteria securely attach themselves to these particles and can move considerable distances, possibly spreading a microbiological risk from one site to another. Sediment transport and hydrodynamic-flow models allow predictions of sediment movement and might be adapted to predict transport of indicators and pathogens.

\section{Microbial Source Tracking and Risk} Assessment: Collaborations with academic institutions are aimed at determining the source of indicators and pathogens that impact beach sands and waters. The data from these and other studies are being used to determine the risk of infection and illness in humans who come in contact with or consume contaminated waters. sands. USGS FISC has been studying factors (for example, nutrient and metal cycling, temperature, salinity, and ultraviolet irradiation) within beach sands that contribute to bacterial survival and persistence.

\section{Improvement of Beach Monitoring} through Research Collaborations:

FISC microbiologists are currently involved in discussions with state and local governments, and universities to establish long-term collaborations for investigations into the causes of repeated closing of specific beaches due to issues affecting microbiological quality. These collaborations include the following issues:

\section{*2005 State of the Beach Report: Bacteria and Sand, A National Call to Action. Clean Beaches Council. July 2005. http://www.cleanbeaches.org/ ewebeditpro/items/O31F6450.pdf}

For more information, please contact:

Christina A. Kellogg

John T. Lisle

U. S. Geological Survey

Florida Integrated Science Center

600 4th Street South

St. Petersburg, FL 33701

Telephone: 727-803-8747

Email: ckellogg@usgs.gov or jlisle@usgs.gov 